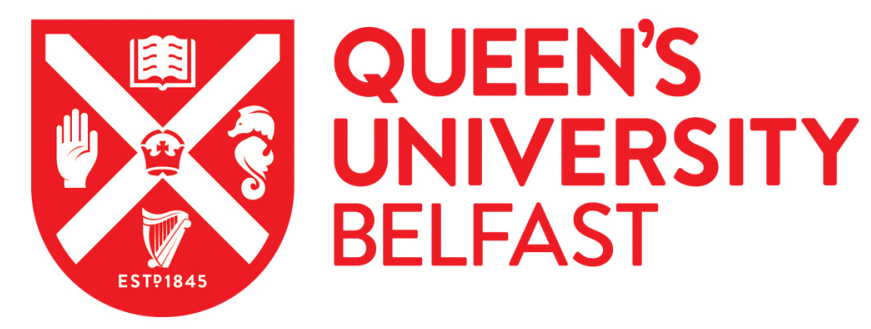

\title{
Sharing services, saving money? Five risks to cost saving when organizations share administrative services
}

Elston, T., \& MacCarthaigh, M. (2016). Sharing services, saving money? Five risks to cost saving when organizations share administrative services. Public Money and Management, 36(5), 349-356.

https://doi.org/10.1080/09540962.2016.1194081

Published in:

Public Money and Management

Document Version:

Peer reviewed version

Queen's University Belfast - Research Portal:

Link to publication record in Queen's University Belfast Research Portal

Publisher rights

Copyright 2016 Taylor and Francis.

This is an accepted manuscript of an article published by Taylor \& Francis in Public Money and Management on 10/06/2016, available online: http://www.tandfonline.com/10.1080/09540962.2016.1194081]."

\section{General rights}

Copyright for the publications made accessible via the Queen's University Belfast Research Portal is retained by the author(s) and / or other copyright owners and it is a condition of accessing these publications that users recognise and abide by the legal requirements associated with these rights.

Take down policy

The Research Portal is Queen's institutional repository that provides access to Queen's research output. Every effort has been made to ensure that content in the Research Portal does not infringe any person's rights, or applicable UK laws. If you discover content in the Research Portal that you believe breaches copyright or violates any law, please contact openaccess@qub.ac.uk. 


\title{
Sharing services, saving money?
}

Five risks to cost saving when organizations share administrative services

\author{
Dr Thomas Elston, University of Oxford \\ Blavatnik School of Government, \\ University of Oxford, \\ Radcliffe Observatory Quarter, \\ Woodstock Road, \\ Oxford OX2 6GG \\ thomas.elston@bsg.ox.ac.uk
}

\author{
Dr Muiris MacCarthaigh, Queens University Belfast \\ School of Politics, International Studies and Philosophy \\ Queen's University Belfast \\ 25 University Square \\ Belfast BT7 1PB \\ m.maccarthaigh@qub.ac.uk
}

\begin{abstract}
Shared services are a popular reform for governments under financial pressure. The hope is to reduce overheads and increase efficiency by providing support services like HR, finance and procurement once to multiple agencies. Drawing on insights from organization theory and political science, we identify five risks that shared services won't live up to current expectations. We illustrate each with empirical evidence from the UK, Ireland and further afield, and conclude with suggestions on how to manage these risks.
\end{abstract}

\section{KEYWORDS}

Centralization, cost saving, efficiency gains, international public sector reform, organization theory 


\section{ACKNOWLEDGEMENTS}

Part of this research was funded by a PhD studentship from the University of Nottingham and a research grant from the Leverhulme Trust. We thank all interviewees for participating in the project.

\section{BIOGRAPHY}

Thomas Elston is Postdoctoral Research Fellow at the Blavatnik School of Government, University of Oxford

Muiris MacCarthaigh is Lecturer in Politics and Public Administration at the School of Politics, International Studies and Philosophy at Queen's University Belfast. 


\section{INTRODUCTION}

Efficiency pressures in the public sector have intensified since the global financial crisis. Declining budgets and rising demand for public services mean that governments are looking for significant cost savings through re-organization. One solution that is proving especially popular is 'shared services' (MacCarthaigh, 2014; Boon \& Verhoest, 2015; Raudla \& Tammel, 2015). Widely favoured in the private sector, this reform removes an organization's administrative and/or professional support functions to a specialist provider, who then offers the same services to multiple clients (Ulrich, 1995; Bergeron, 2003). The aim is to reduce duplication in areas like HR, finance and procurement, harness economies of scale, and promote investment and professionalization. This should deliver corporate support that is both higher quality and significantly cheaper.

Despite some noteworthy successes and widespread enthusiasm among consultants and policy institutes (PWC, 2009; LGA, 2012; AGA \& Accenture, 2015; OECD, 2015; Shared Services Leadership Coalition, 2015), it is increasingly apparent that shared services are no fail-safe efficiency solution. Delays, cost overruns and deteriorating service quality are commonplace (NAO, 2008, 2011; Economic Regulation Authority, 2011; Chesterman, 2013), and disillusionment is beginning to set in. Peter Gershon, the British businessman and government adviser who initially recommended shared services in $\mathbf{2 0 0 4}$, later conceded that difficulties in implementation mean the reform "should only be undertaken on a very carefully selected and controlled basis" (Gershon, 2008). Problems have also occurred in Belgium, the Netherlands and Estonia (Wagenaar, 2006; Boon \& Verhoest, 2015; Raudla \& Tammel, 2015), and the Australian Government recently cautioned that: "There are plenty of examples ... where a good idea that is not well implemented leads to increased costs and/or poorer service standards" (Australian Public Service Commission, 2013, p.7). Even in the private sector, $60 \%$ of shared services projects reportedly fall behind their original business case (Briskman, 2015).

Given these problems, this article re-examines the cost-saving potential of shared services for governments under financial pressure. Our inspiration comes from organization theory and political science - perspectives largely absent from existing literature. After a brief account of the reform idea and its growing 
popularity, we identify five risks that savings won't be realized. We illustrate each with evidence from the UK, Ireland and further afield, and conclude with recommendations on how to manage these risks.

\section{SHARED SERVICES IN GOVERNMENT}

\section{What are shared services?}

There are certain administrative and professional functions that most organizations perform, irrespective of their primary objectives. These support the enterprise to deliver its goals and meet regulatory requirements - for example, by recruiting personnel, purchasing goods and services, or providing analysis and advice (Huijben et al., 2013). Finance, procurement, human resources, information technology, estates, legal services and internal audit are examples of these 'corporate services'. Some functions are fairly standardized (like payroll), while others require customization. Yet overlap is sufficient to ask whether this activity is best performed in-house or whether it can be consolidated between multiple organizations (Elston, 2015).

This question has long exercised administrative scientists, who find tradeoffs between in-house and "common" services (Gulick, 1937). Internalization means that a single line of authority directs all the resources upon which the organization depends. Services can be designed for specific purposes, delivered to individual timetables, and resourced according to immediate priorities. But in-house production is often more expensive, with lower volumes of activity bringing higher unit costs and prohibiting strategic investment. Alternatively, the higher workload achieved when organizations share support services often brings lower unit costs, better use of technology and greater expertise, albeit at the expense of some responsiveness and customization.

Given these trade-offs, historically, governments and industry alike have cycled between alternative corporate service arrangements. The advent of M-form companies in the 1960 -70s relaxed the administrative centralization of previously favoured U-forms (Williamson, 1985), while decentralization during the 1980s-90s undid many common services in public bureaucracies (Barzelay, 1992). Current enthusiasm for shared services thus represents a further oscillation of this de/centralisation cycle, though today's reformers opine that ICT and quasi- 
marketization (pay-per-use charging, customer choice) differentiate shared services from prior models (Ulrich, 1995; Bergeron, 2003).

Figure 1 compares four arrangements for corporate support. Models (ii)-(iv) involve some inter-organizational sharing, but differ by how many clients are served, their proximity to the vendor, and whether the private sector is involved. Further variation comes from whether high-volume transactional functions (invoicing, vacancy listing) or high-skill professional services (legal advice) are consolidated; how the different parties interact (informal negotiation, service level agreements, contracts); and how clients are related to one another (geographically, by policy sector, or not at all). More research is needed into how these attributes correlate, but implementation style appears relevant (Raudla \& Tammel, 2015). Shared services can be imposed on agencies by higher authorities, or can emerge voluntarily (see OECD, 2015). The bottom-up approach tends to favour small-scale joint ventures, whereas top-down implementation allows larger-scale insourcing or coordinated outsourcing.

\section{> >FIGURE<<<}

\section{Where, when and how?}

The shared services terminology emerged in the private sector during the 1980s, initially for treasury and accounting. In government, it first appeared at state-level in Australia and Canada in the 1990 (Juozapavicius, 2000). These reforms expanded after 2000, and found favour elsewhere, including in public healthcare in the UK and New Zealand (Day \& Norris, 2006; Redman et al., 2007), and local government in Germany (Niehaves \& Krause, 2010). Interest also grew at the national level, starting with information systems in America (GAO, 2006) but soon expanding into other functions in a variety of countries.

The 2007-08 global financial crisis gave new impetus, prompting more urgent and ambitious reforms in many local, regional and national governments around the world. Table 1 describes some recent initiatives, illustrating the widespread appeal and varied implementation of the shared services concept. It includes single-sector consolidations in British Columbia and the Netherlands, 
alongside cross-sector schemes in Sweden and Denmark. Some vendors provide only one function, as in Canada, whereas others are multifunctional. Funding mechanisms vary, but governance tends towards the (ii) joint venture and (iii) insourcing types, although there are other examples of public-private partnering and full outsourcing (see Mclvor et al., 2011).

$\gg \gg$ TABLE $<<<$

\section{Why shared services?}

Despite the variety of reforms in Table 1 , there is general agreement on the intended benefits. These include greater management focus on primary objectives, increased customer satisfaction, and better career prospects for specialist staff. Yet, the most prominent rationale is cost reduction. Expected savings vary, but claims of 25-45 per cent are common (Accenture, 2005; Shared Services Leadership Coalition, 2015). Thus, up to $£ 8 b n$ is reportedly available from reform in the UK (PWC, 2009), and \$47bn from US federal government (AGA \& Accenture, 2015). Most savings derive from the aggregation of workload. Higher volumes allow a finer 'division of labour,' enhancing productivity. Consolidation also allows better handling of fluctuating demand, ensuring staff and infrastructure are never underutilized. And investment thresholds are lower when organizations work in partnership, allowing greater access to automation or professional expertise (see Murray et al., 2008). Additionally, consolidation might reduce client demand on support services through improved management information, and can bring additional revenue if services are sold to third parties (see LGA, 2012).

Given these promises, governments are under growing pressure to adopt some sort of shared services programme. In 2005, one consultant urged public managers: "If you are not already thinking about moving to shared services for your organisation, you probably should be" (Accenture, 2005, p.36). Since then, budget cuts have only increased this imperative, as spending is prioritized on frontline public services. However, the benefits of reform are proving hard to realize in practice. Projects in the UK transport and research funding sectors exceeded their start-up budgets by $105 \%$ ( $(558 \mathrm{~m})$ and $65 \%\left(f_{51 \mathrm{~m}}\right)$, respectively (NAO, 2008, 2011). Difficulties in the Netherlands, Queensland and Western Australia led to 
programmes being cancelled midway through implementation (Wagenaar, 2006; Economic Regulation Authority, 2011; Chesterman, 2013). In New South Wales, initially, only $5 \%$ of expected savings were realized (Dollery \& Grant, 2009, p.45). And a recent survey of US public agencies found nearly half failed to achieve any savings, with a quarter actually reporting cost increases (Schwarz, 2014, pp.191192).

Research has begun to explore these problems in general terms (Borman \& Janssen, 2013; Knol et al., 2014), but as yet there is no explanation for why cost saving specifically can go so awry. Consequently, below we look to political science and organization theory to identify five key risks: escalating start-up costs, increased transaction costs, reduced service quality, functional duplication and opportunity costs. We illustrate each with interview data and published audits from the UK and Ireland, which are undergoing major reforms (DPER, 2011; HM Government, 2012), as well as with secondary literature from further afield. Interviews were part of separate research projects examining recent trends in administrative reform.

\section{FIVE RISKS TO COST SAVING THROUGH SHARED SERVICES}

\section{Escalating start-up costs due to path dependence}

Beginning with reform development, while there are cases of shared services being delivered on time and budget (LGA, 2012; Controller and Auditor-General, 2014), often there are delays and significant cost overruns (NAO, 2008, 2011; Economic Regulation Authority, 2011; Chesterman, 2013; NIAO, 2013). This reflects the difficulty of refashioning organizations to enable service sharing. Change resistance has long been observed in bureaucracies (Downs, 1966; Hannan \& Freeman, 1984). Emotional attachments, cognitive biases and internal politics partly explain such inertia (see Sydow et al., 2009, pp.693-694), and certainly account for some problems with shared services, for which staff resistance is widely reported (GAO, 2006; Mclvor, et al., 2011; Boon \& Verhoest, 2015). Yet there are many other reasons for organizational 'lock-in' which might explain the reported difficulties. One is path dependence. 
Path dependence occurs when "each step along a particular path produces consequences which make that path more attractive" (Pierson, 2000, pp.253, 252). Various self-reinforcing mechanisms gradually affect the balance of choice between continuity and change, increasing "the costs of exit - of switching to some previously plausible alternative." These mechanisms include: high start-up and fixed costs, which commit organizations to amortizing an initial investment over time; interdependencies between systems, which produce a 'drag' on changing any single element; and learning effects, where familiarity (not change) increases productivity (Pierson, 2000; Sydow, et al., 2009). Together, these forces "render a system potentially inefficient, because it loses its capacity to adopt better alternatives" (Sydow, et al., 2009, p.692).

Path dependence explains cost overruns in shared service projects by the unexpected difficulties of breaking these self-reinforcing mechanisms. Firstly, in terms of fixed and start-up costs, as Downs (1966, p.195) explains: "established processes [in organizations] represent an enormous previous investment in time, effort, and money." Sometimes, the price of foregoing this prior investment is obvious, as when shared services bring staff redundancies $(N A O, 2008)$ or penalties for leaving existing contracts early (Hall, 2014). But often costs are hidden; for instance, when abandoning existing technology that has yet to run its full economic life. Such an unnecessary reduction in the value-for-money of prior investments must be carefully weighed against the benefits of changing path, and might bias decision-makers towards the status quo.

Secondly, unforeseen or underestimated interdependencies between backoffice and frontline systems can increase start-up costs for shared services. This has been a recurrent issue in US federal government (GAO, 2006), and also caused significant problems in the UK transport sector, where it was only latterly realized that technology developed for a new shared services platform also needed to align with cross-governmental security regulations (NAO, 2008).

Finally, in terms of learning effects that create path dependency, it takes time for a new system's capabilities, quirks and dysfunctions to be observed and accommodated by staff operatives. This causes an initial dip in productivity, as reported in both the Netherlands and Western Australia when new "self-service" 
portals required untrained staff to process their own HR transactions online (Economic Regulation Authority, 2011; Meijerink \& Bondarouk, 2013).

The cost of breaking these three self-reinforcing mechanisms are often underestimated. In extreme cases, so great do the difficulties turn out to be that, were they recognized from the start, the reforms might never have been approved. For example, shared services in Western Australia cost \$362mAUD more than planned, and in hindsight should never have proceeded (Economic Regulation Authority, 2011). As one of our Irish interviewees summarized:

"Shared services is a very good idea on paper, and a very difficult ... product to put into place. ... [Y]ou've got to put a huge effort into it. Sometimes...the effort would be far greater...than actually the result you would deliver..."

\section{Increased transaction costs}

In economic terms, organizations incur both production costs and transaction costs. These represent the price of turning inputs into outputs, and of arranging and monitoring those processes. Both costs should be minimized, but often there is a trade-off. Externalization lowers production costs for standard items due to scale economies, but can bring higher transaction costs than if managers oversee the work directly (Williamson, 1985). As Coase (1960, p.15) explains:

"In order to carry out a market transaction it is necessary to discover who it is that one wishes to deal with, to inform people that one wishes to deal and on what terms, to conduct negotiations leading up to a bargain, to draw up the contract, to undertake the inspection needed to make sure that the terms of the contract are being observed, and so on. These operations are often extremely costly...."

Thus, in order to achieve a net efficiency gain from sharing corporate services, production-cost savings must outweigh any increase in transaction costs.

Shared services involve various transaction costs. Initially, great effort might be needed to document how the back-office currently operates. As Cohen et al. (1976, p.25) explain, often an organization's "own processes are not understood by its members. It operates on the basis of simple trial and error procedures, the residue of learning from the accidents of past experience, and pragmatic inventions of necessity." Codifying such a haphazard system is essential if it is to be delegated to a third party, but this task is costly and liable to be rushed. For instance, in New Zealand's recent reforms, "the most significant problem ... was a lack of 
thoroughness in gathering information ... for working out what [the vendor] needed to include in its scope" (Controller and Auditor-General, 2014, p.18). Similarly, limited understanding of internal processes led to unforeseen interdependencies in Sweden (Ulbrich, 2006, p.200), and to poorly-specified (and expensive) ICT contracts in several UK cases (NAO, 2008, 2011).

Transaction costs also arise when client organizations attempt to standardize their back-office processes - a necessity for unit cost savings. As the research literature on inter-organizational collaboration reveals, it is often difficult and time consuming to reach agreement between multiple independent parties, and can involve considerable "process" costs (McGuire and Agranoff, 2011). As a shared services employee in the NHS reported: "[Different clients] all want different things and you get caught in the middle. ... They are all pulling in different directions" (see Redman, et al., 2007, p.1500). Moreover, if unresolved, such disagreements can result in excessive customization of services, lowering production-costs savings. This problem has been widely reported.

A third source of transaction costs is the increased coordinative burden when functions are split between vendors and clients. As Fraser (1954, pp. 256-257) explained of the UK's old "common service" arrangements from the 1950s:

\footnotetext{
"There is ... a new labour for top management ... of coordinating the work of the common service with that of the executive lines which it serves. There is the additional labour of explaining to the common service what is required.... There is ... some waste work because of misunderstanding. There is also more to-and-fro, more paper and records of all sorts, more talk and more meetings and more committees."
}

Although new technologies might lessen this burden somewhat, recent research in Estonia still found that shared services required "several additional organizational levels ... [in] the coordination processes" (Raudla \& Tammel, 2015, p.172).

Overall, the economic perspective reveals that administrative consolidation is not necessarily efficient. It depends on the balance of production costs and transaction costs. Reform proponents often overlook this trade-off, focusing on unit-cost savings rather than the transaction-cost burden for clients - a practice recently condemned by several government auditors (Economic Regulation Authority, 2011; Office of the Auditor General of Canada, 2015). Likewise, some of our interviewees complained about poor recognition of client costs: 
"For a department of [large] size, we actually had a very lean HR division per head of staff, so we had a cheap enough system. So, in migrating [to a shared service], we were going to a more expensive system..."

"[T]he department wants you to go onto their shared services, but what happens if it actually costs you more? 'Cause we're in the position where, actually, to move over to some of the shared services ... would cost us more than the way we're doing things at the moment."

\section{Reduced service quality}

Inter-agency standardization of back-office processes, which is required to achieve unit-cost savings, is enforced through rules and regulations. This aids coordination, but, according to organizational sociology, also bring several risks, including excessive concern for processes over outcomes, slower decision-making and decreased innovation (Merton, 1952; Thompson, 1965; Downs, 1966) - all of which can damage service quality and inflate costs.

"Goal displacement" occurs in organizations when "adherence to the rules, originally conceived as a means, becomes transformed into an end-in-itself" (Merton, 1952, p.365). This is a familiar criticism of public bureaucracies generally, inspiring many administrative reforms in the 1980s-90s (Barzelay, 1992). Although contemporary shared services enthusiasts acknowledge the need for vendors to remain responsive to clients - as Ulrich (1995) writes, "the user is the chooser" - this remains difficult in practice, as one UK interviewee explained:

"[When you have] a great big, monolithic, potentially-monopsonistic supplier ... then you start getting Shared Services and Procurement having policies and ideas of their own, and their idea about what your business should be. And [they] stop acting like the provider, and start acting like the customer."

The official proceeded to recall such an incident of the "tail wagging the dog," where the vendor's concern for adhering to processes undermined the client's focus on policy outcomes. As they vented: "Why are we here in government: to provide prisons and courts and hospitals, or to provide procurement?"

Regulation is also associated with slower organizational decision-making for non-routine matters, which must be referred up the hierarchy before a new rule can be made (Downs, 1966). Historically, Fraser (1954, p.257) warned that "Common services slow down the passage of business." Again, despite technological advancements, this remains a concern today, with a senior UK official remarking: 
"It's a difficult journey to get to a place where a shared service model ... isn't a brake on the business."

Finally, heavily regulated organizations have also been associated with reduced innovation, the detailed specification of resources and procedures dampening creativity (Thompson, 1965). This concern was implicit in one UK interviewee's account of the irony of working in a semi-independent public agency that was nonetheless forced to adopt shared services:

"Shared services - that's where the departmental mandate comes out. ... You know: 'Agencies - yes, you're free to deliver [as you want], but you'll use this IT, you'll use that HR, you'll use that procurement..."'

Together, goal displacement, slower decision-making and dampened innovation not only damage service quality, but also have cost implications - for example, if vendor mistakes have to be corrected or client organizations start duplicating poorly-performing functions in-house (see Risk 4, below).

\section{Functional duplication}

Sharing services should eliminate duplicated activity, over-capacity and 'redundancies' in public agencies. However, the emergence of shadow teams in client organizations, repeating the work of vendors, is a well-known postconsolidation risk to efficiency (Ulrich, 1995, p.23), lowering the volume of shared transactions and undermining scale economies.

There are many possible explanations for continued duplication of functions after the adoption of shared services. Some theorists argue that bureaucrats naturally prefer autonomy and seek to maximize this whenever possible (Downs, 1966). This perspective is implicit in existing discussions of agency resistance to shared services (Mclvor, et al., 2011; Boon \& Verhoest, 2015). A more nuanced account is that officials value prestigious policy work rather than mundane operations (Dunleavy, 1991). This suggests that high-skill professional services, rather than high-volume administrative processing, is more likely to be duplicated in-house (although as yet there is no research evidence for this).

An alternative explanation comes from institutional theory. Since at least the 1970s, it has been recognized that organizations gain legitimacy by adhering to dominant societal beliefs about what 'good management' looks like (Meyer \& 
Rowan, 1977). But these cultural scripts often conflict with the demands of internal efficiency. Consequently, organizations might 'decouple' their public-facing exterior from their internal operations, operating differently in public than in private (Elston 2016). This means paying lip service to fashionable reforms, such as shared services, while retaining (and concealing) in-house capacity, if this is thought beneficial to day-to-day management. There is some evidence to support this institutional explanation for shadow teams emerging after shared service adoption. In Estonia, amid strong pressure for reform, client agencies created '"parallel' accounting systems which served their own special purposes and informational needs better [than the vendor]" (Raudla \& Tammel, 2015, p.172). Similarly, in the UK, fear about sharing the internal audit and assurance function between organizations brought the risk of concealed duplication, as one interviewee remarked:

"If you start to do things like that, then, at worst what'll happen is an Accounting Officer will think 'Oh well, they can do what they like, but I'm gonna have my own internal audit, and I'll call it something else' - and that defeats the object of the exercise, really. [The Accounting Office will] probably be getting his internal auditors to look at what really matters to him, and fobbing the other one off with anything else..."

A third explanation for duplication is that, despite conventional wisdom, organizational redundancies can actually be efficient if they increase system reliability and resilience (Landau, 1969; Lerner, 1986). As Lerner (1986, p.335) explains, "Without duplication, the breakdown of one organizational channel leaves no other duplicate channel available for backup." Thus, shadow teams might emerge as a fail-safe. For example, a survey of finance officials in Northern Ireland found the majority were supplementing shared accounting services in order to "double-check" the vendor's work (NIAO, 2013, pp.41, 52). This partly explains why staff savings were less than expected.

\section{Opportunity costs}

Finally, as with any reform, there are opportunity costs to adopting shared services - especially in the current fiscal climate. Human and financial resources are limited, and leaders face choices and forego alternatives when one reform option is selected over another. So the question arises: by focusing particularly on shared 
services, what are governments not doing, and is this sacrifice worthwhile from a cost-saving perspective?

Shared services might indeed enable economies of scale, scope and learning; but there is also much to be gained by the reverse strategy of devolving decisions and resources to individual agencies. This approach, which was favored in the $1980 \mathrm{~s}$ and 1990s, brings its own challenges in coordination and control, but it does reduce the bureaucratic burden on the frontline and potentially increase agility and innovation. These can contribute to cost saving, but are difficult to achieve when the main thrust of reform is centralization.

Furthermore, the major restructuring required for shared services might distract from the underlying aim of streamlining complex back-office processes, or might divert attention away from the much greater challenge of reshaping frontline systems and processes (which, after all, is where the majority of public money is spent). This is not to suggest that administrative cost-saving is not possible or desirable, but that less resource-intensive alternatives to full shared services might be more productive overall if they free up capacity for other reforms to be pursued simultaneously.

\section{CONCLUSIONS}

There is no denying that shared services have recently found widespread favour in governments around the world, albeit with great variation in scale and style. In current circumstances, the promise of major efficiency gains is extremely attractive. But faced with a series of disappointments, this article has re-examined the cost-saving potential of shared services, drawing on hitherto underused ideas from organization theory and political science.

Our findings essay a distinctly cautionary message. Although the difficulties of implementation are increasingly recognized, few commentators have questioned the "tremendous theoretical potential" for shared services to deliver savings to cash-strapped organizations (Ulbrich, 2006, p.196). As Briskman (2015) urges, "The business case ... often writes itself." Yet we have illustrated a range of possible sideeffects - from increased transaction costs, to goal displacement and the loss of failsafe redundancies - that might actually damage organizational efficiency, long after 
the initial restructuring is over. And this list is not exhaustive. We might also have mentioned the risk of becoming locked-in to inflexible contracts (Mclvor, et al., 2011), or the difficulty of retaining sufficient in-house expertise to be an "intelligent customer" of the vendor (Bovaird, 2016). Of course, these are all only potential sideeffects - or risk factors. Their incidence no doubt varies by context, and an important question for future research is to explain this variation. Why do some shared service reforms work better than others? Nonetheless, on the basis of the above, we must refute the popular suggestion that shared services are inherently a superior method of delivering corporate support to organizations. Rather, following the "contingency" view of organizations, which emphasizes the role of context in determining effective organisational design (Donaldson, 2001), it seems that multiple factors must be carefully weighed before shared services can be judged appropriate for a particular set of circumstances.

In conclusion, we offer the following advice to practitioners and a final note about future research in this area.

\section{Policy implications}

1) Explore all options. Shared services should be evaluated as one of a range of options for improving administrative efficiency. Sometimes they will be the best choice. Sometimes they will not, with reforms to in-house provision preferable. This is especially likely if transaction costs are high or clients have diverse needs. And sometimes, key benefits like streamlined processes and joint acquisition of technology might be achieved without full structural aggregation, with all its attendant challenges. Indeed, the UK's National Audit Office (2012, p.26) recently cast a rather damning verdict on shared services by arguing that "many of the benefits generated [so far] could have been achieved by other means or with lower investment."

2) Confront the trade-offs. Rarely does organizational change deliver all benefit for no cost, no matter how the reform is "sold" to key stakeholders. As noted, there are often trade-offs between production and transaction costs, and between inefficient and fail-safe redundancies. Explicitly recognizing these 
dilemmas will improve initial cost-benefit analysis and indicate areas for subsequent risk monitoring and management.

3) Use 'negative' feedback. Often, staff resistance to shared services is interpreted as unhelpful bureaucratic obstinacy. This is simplistic. Self-interest is indeed one explanation, but there are many other causes of reluctance that reflect genuine problems with the shared services idea. Hence, negative feedback is not simply a "people issue" to be dealt with by appropriate change management, but is also an opportunity to engage end-users in reform design and implementation. For instance, clients can highlight where costs are being transferred from vendors to users, rather than fully eliminated (Office of the Auditor General of Canada, 2015).

\section{Note for research}

Finally, given current fiscal pressures around the world, it is important that shared services receive further research attention over the coming years. One lesson from this article is that, despite frequent claims of newness, interorganizational corporate services are really an old invention that has gone through phases of popularity and decline in both government and industry. Whether new technologies or quasi-marketization help to overcome previous difficulties with the common services idea is not a matter to be taken for granted, but an important research question to be tested empirically. Indeed, by recognizing this lineage, and the cyclical pressures that prompt consolidation and fragmentation in organizations, we can begin to provide suitable advice to public managers on how to sort out the reasonable from the outlandish claims currently being made about the benefits of sharing services.

\section{REFERENCES}

Accenture. (2005). Driving High Performance in Government: Maximising the Value of Public-Sector Shared Services. London.

AGA \& Accenture. (2015). The Pursuit of Government Efficiency: Opportunities to Advance Federal Shared Services. Alexandria.

Australian Public Service Commission. (2013). State of the Service Report. Canberra

Barzelay, M. (1992). Breaking Through Bureaucracy. Berkeley: University of California Press. 
Bergeron, B. (2003). Essentials of Shared Services. Hoboken: Wiley.

Boon, J., \& Verhoest, K. (2015). Masters or puppets? Agency reactions in response to SSC reform pressures. Paper presented at the International Conference on Public Policy, Milan.

Borman, M., \& Janssen, M. (2013). Reconciling two approaches to critical success factors: The case of shared services in the public sector. International Journal of Information Management, 33(2), 390400.

Bovaird, T. (2016). The ins and outs of outsourcing and insourcing: What have we learnt from the past 30 years? Public Money \& Management, 36(1), 67-74.

Briskman, S. (2015, Spring). Shared services - don't be in the 60\% which fail to deliver. Professional Outsourcing Magazine.

Chesterman, R.N. (2013). Queensland Health Payroll System Commission of Inquiry. Brisbane.

Coase, R.H. (1960). The problem of social cost. Journal of Law and Economics, 3, 1-44.

Cohen, M.D., March, J.G., \& Olsen, J.P. (1976). People, problems, solutions and the ambiguity of relevance. In J.G. March \& J.P. Olsen (eds.), Ambiguity and Choice in Organizations (pp. 24-37). Bergen: Universitetsforlaget.

Controller and Auditor-General. (2014). Setting up Central Agencies Shared Services. Wellington.

Day, K.J., \& Norris, A.C. (2006). Supporting information technology across health boards in New Zealand: themes emerging from the development of a shared services organization. Health Informatics Journal, 12(1), 13-25.

Department of Public Expenditure and Reform (DPER). (2011). Public Service Reform. Dublin.

Dollery, B., \& Grant, B. (2009). Tortoises and hares: The race to shared services across Australian state and territory jurisdictions. International Journal of Public Administration, 33(1), 43-54.

Donaldson, L. (2001). The Contingency Theory of Organizations. Thousand Oaks: Sage.

Downs, A. (1966). Inside Bureaucracy. Boston: Little, Brown.

Dunleavy, P. (1991). Democracy, Bureaucracy and Public Choice. London: Prentice Hall.

Economic Regulation Authority. (2011). Inquiry into the Benefits and Costs Associated with the Provision of Shared Corporate Services in the Public Sector. Perth.

Elston, T. (2015). To share or not to share? Delivering corporate services in 21st-century government. Blavatnik School of Government Policy Memo Series. Oxford.

Elston, T. (2016). Conflict between explicit and tacit public service bargains in UK executive agencies. Governance, DOI: 10.1111/gove.12191.

Fraser, R. (1954). The virtues and vices of common services. Public Administration, 32(3), 253-263.

Gershon, P. (2008). Review of the Australian Government's Use of Information and Communication Technology. Canberra: Department of Finance and Deregulation.

Government Accountability Office (GAO). (2006). Financial Management Systems: Additional Efforts Needed to Address Key Causes of Modernization Failures. Washington DC.

Gulick, L. (1937). Notes on the theory of organization. In L. Gulick \& L. Urwick (eds.), Papers on the Science of Administration. Concord: Rumford.

Hall, K. (2014, 30th June). MoJ axes f127m IT project, Law Society Gazette.

Hannan, M.T., \& Freeman, J. (1984). Structural inertia and organizational change. American Sociological Review, 49(2), 149-164.

HM Government. (2012). Next Generation Shared Services. London: Cabinet Office.

Huijben, M., Geurtsen, A., \& van Helden, J. (2013). Managing overhead in public sector organizations through benchmarking. Public Money \& Management, 34(1), $27-34$. 
Juozapavicius, D. (2000). Building consensus. Institute of Public Administration of Canada Case Study Programme.

Knol, A., Janssen, M., \& Sol, H. (2014). A taxonomy of management challenges for developing shared services arrangements. European Management Journal, 32(1), 91-103.

Landau, M. (1969). Redundancy, rationality, and the problem of duplication and overlap. Public Administration Review, 29(4), 346-358.

Lerner, A.W. (1986). There is more than one way to be redundant. Administration \& Society, 18(3), 334-359.

Local Government Association (LGA). (2012). Services Shared: Costs Spared?. London.

MacCarthaigh, M. (2014). Shared services in Ireland. In P. Lægreid, K. Sarapuu, L.H. Rykkja \& T. Randma-Liiv (Eds.), Organizing for Coordination in the Public Sector (pp. 54-65). Basingstoke: Palgrave Macmillan.

McGuire, M., \& Agranoff, R. (2011). The limitations of public management networks. Public Administration, 89(2), 265-284.

Mclvor, R., McCracken, M., \& McHugh, M. (2011). Creating outsourced shared services arrangements: lessons from the public sector. European Management Journal, 29(6), 448-461.

Meijerink, J., \& Bondarouk, T. (2013). Exploring the central characteristics of HR shared services: evidence from a critical case study in the Netherlands. International Journal of Human Resource Management, 24(3), 487-513.

Merton, R.K. (1952). Bureaucratic structure and personality. In R.K. Merton, A.P. Gray, B. Hockey \& H.C. Selvin (eds.), Reader in Bureaucracy (pp. 361-371). Glencoe: Free Press.

Meyer, J.W., \& Rowan, B. (1977). Institutionalized organizations: formal structure as myth and ceremony. American Journal of Sociology, 83(2), 340-363.

Murray, J.G., Rentell, P.G., \& Geere, D. (2008). Procurement as a shared service in English local government. International Journal of Public Sector Management, 21(5), 540-555.

National Audit Office (NAO). (2008). Shared services in the Department for Transport and its agencies. London.

NAO. (2011). Shared services in the Research Councils. London.

NAO. (2012). Efficiency and Reform in Government Corporate Functions through Shared Service Centres. London.

Niehaves, B., \& Krause, A. (2010). Shared service strategies in local government. Transforming Government: People, Process and Policy, 4(3), 266-279.

Northern Ireland Audit Office (NIAO). (2013). Account NI: Review of a Public Sector Financial Shared Services Centre. Belfast.

Office of the Auditor General of Canada. (2015). Report 4: Information Technology Shared Services. Ottawa.

Organisation for Economic Co-Operation and Development (OECD). (2015). Building on Basics: Value for Money in Government. Paris.

Pierson, P. (2000). Increasing returns, path dependence, and the study of politics. American Political Science Review, 94(02), 251-267.

PricewaterhouseCoopers (PWC). (2009). Freeing the Front Line: Where Next for Corporate Shared Services in the Public Sector?. London.

Raudla, R., \& Tammel, K. (2015). Creating shared service centres for public sector accounting. Accounting, Auditing \& Accountability Journal, 28(2), 158-179.

Redman, T., Snape, E., Wass, J., \& Hamilton, P. (2007). Evaluating the human resource shared services model: evidence from the NHS. International Journal of Human Resource Management, 18(8), 1486-1506. 
Schwarz, G. (2014). Public Shared Service Centres. Springer Gabler.

Shared Services Leadership Coalition. (2015). Federal Shared Services: Why Legislation is Necessary. Washington DC.

Sydow, J., Schreyögg, G., \& Koch, J. (2009). Organizational path dependence: opening the black box. Academy of Management Review, 34(4), 689-709.

Thompson, V.A. (1965). Bureaucracy and innovation. Administrative Science Quarterly, 10(1), 1-20.

Ulbrich, F. (2006). Improving shared service implementation: adopting lessons from the BPR movement. Business Process Management Journal, 12(2), 191-205.

Ulrich, D. (1995). Shared services: from vogue to value. Human Resource Planning, 18(3), 12-23.

Wagenaar, R.W. (2006). Governance of shared service centres in public administration: dilemmas and trade-offs. Paper presented at the International Conference on Electronic Commerce.

Williamson, O.E. (1985). The Economic Institutions of Capitalism. New York: Free Press. 


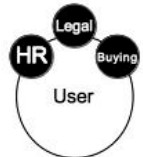

(i) In-house

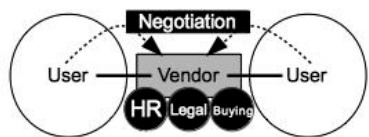

(ii) Joint venture

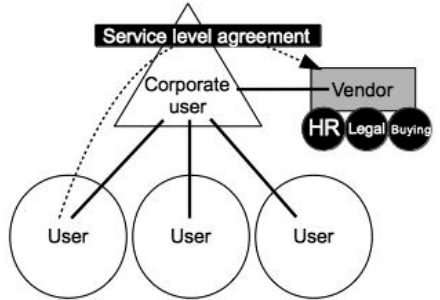

(iii) Insourcing

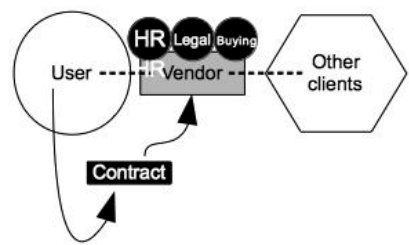

(iv) Outsourcing

\begin{tabular}{|c|c|c|c|c|}
\hline Country & $\begin{array}{c}\text { Example } \\
\text { (Year created) }\end{array}$ & Scale & Scope & Governance \\
\hline New Zealand & $\begin{array}{l}\text { Central Agencies } \\
\text { Shared Services } \\
\text { (2012) }\end{array}$ & $\begin{array}{l}\text { Vendor: 91staff } \\
\text { Clients: } 3 \\
\text { departments in } \\
\text { the core } \\
\text { executive, } \\
\text { 70ostaff }\end{array}$ & $\begin{array}{l}\text { Finance, } \\
\text { information } \\
\text { management, ICT, } \\
\text { HR }\end{array}$ & $\begin{array}{l}\text { Business unit of } \\
\text { Treasury } \\
\text { Co-governed by } \\
\text { clients }\end{array}$ \\
\hline \multirow[t]{2}{*}{ Canada } & $\begin{array}{l}\text { Shared Services } \\
\text { Canada (2011) }\end{array}$ & $\begin{array}{l}\text { Vendor: } \\
\text { 6, ooostaff } \\
\text { Clients: } 43 \\
\text { organisations } \\
\text { across the } \\
\text { federal } \\
\text { government }\end{array}$ & $\begin{array}{l}\text { Mandatory and } \\
\text { optional ICT }\end{array}$ & $\begin{array}{l}\text { Separate } \\
\text { government } \\
\text { department } \\
\text { Shares a } \\
\text { government } \\
\text { minister, with } \\
\text { clients on } \\
\text { departmental } \\
\text { boards } \\
\text { Pay-per-use } \\
\text { funding }\end{array}$ \\
\hline & $\begin{array}{l}\text { Health Shared } \\
\text { Services BC (2010) }\end{array}$ & $\begin{array}{l}\text { Vendor: } \\
\text { 1,500staff } \\
\text { Clients: } 7 \text { health } \\
\text { authorities in } \\
\text { British Columbia }\end{array}$ & $\begin{array}{l}\text { Accounts } \\
\text { Receivable, } \\
\text { Employee Records } \\
\text { \& Benefits, Payroll, } \\
\text { Supply Chain, ICT. }\end{array}$ & $\begin{array}{l}\text { Hosted by one } \\
\text { health authority } \\
\text { Management } \\
\text { board includes } \\
\text { CEOs of client } \\
\text { organisations } \\
\text { Co-funded by } \\
\text { clients, with } \\
\text { savings returned } \\
\text { to them }\end{array}$ \\
\hline \multirow[t]{2}{*}{ Australia } & $\begin{array}{l}\text { Shared Services } \\
\text { Centre (2014) }\end{array}$ & $\begin{array}{l}\text { Vendor: 6oostaff } \\
\text { Clients: } 32 \\
\text { organisations in } \\
\text { federal } \\
\text { government }\end{array}$ & $\begin{array}{l}\text { Optional payroll, } \\
\text { financial } \\
\text { processing, ICT, } \\
\text { communications, } \\
\text { estates. }\end{array}$ & $\begin{array}{l}\text { Started by the } \\
\text { Departments of } \\
\text { Education and } \\
\text { Employment } \\
\text { Pay-per-use } \\
\text { funding }\end{array}$ \\
\hline & $\begin{array}{l}\text { Shared Services } \\
\text { SA (2010) }\end{array}$ & $\begin{array}{l}\text { Vendor: 819staff } \\
\text { Clients: } \\
\text { organisations in } \\
\text { Southern } \\
\text { Australia }\end{array}$ & $\begin{array}{l}\text { Payroll and financial } \\
\text { services; ICT } \\
\text { recently devolved } \\
\text { back to clients }\end{array}$ & $\begin{array}{l}\text { Business unit of } \\
\text { Department of } \\
\text { the Premier and } \\
\text { Cabinet } \\
\text { Shares a } \\
\text { government }\end{array}$ \\
\hline
\end{tabular}




\begin{tabular}{|c|c|c|c|c|}
\hline & & & & $\begin{array}{l}\text { minister } \\
\text { Grant funded }\end{array}$ \\
\hline Sweden & $\begin{array}{l}\text { Statens } \\
\text { servicecenter } \\
(2012)\end{array}$ & $\begin{array}{l}\text { Vendor: 340staff } \\
\text { Clients: } \\
\text { 70,6oostaff }\end{array}$ & $\begin{array}{l}\text { Payroll, finance, } \\
\text { procurement }\end{array}$ & $\begin{array}{l}\text { Separate } \\
\text { government } \\
\text { agency } \\
\text { Pay-per-use } \\
\text { funding }\end{array}$ \\
\hline Denmark & $\begin{array}{l}\text { Statens } \\
\text { Administration } \\
(2011)\end{array}$ & $\begin{array}{l}\text { Vendor: } 350 \text { staff } \\
\text { Clients: } 160 \\
\text { organisations } \\
\text { across national } \\
\text { government }\end{array}$ & $\begin{array}{l}\text { Payroll, financial } \\
\text { services }\end{array}$ & $\begin{array}{l}\text { Separate } \\
\text { government } \\
\text { agency } \\
\text { Grant funded }\end{array}$ \\
\hline $\begin{array}{l}\text { The } \\
\text { Netherlands }\end{array}$ & $\begin{array}{l}\text { Police Service } \\
\text { Centre (2011) }\end{array}$ & $\begin{array}{l}\text { Vendor: } \\
6,200 \text { staff } \\
\text { Clients: regional } \\
\text { police forces, } \\
64,000 \text { staff }\end{array}$ & $\begin{array}{l}\text { Payroll, ICT, } \\
\text { procurement, } \\
\text { estates }\end{array}$ & Grant funded \\
\hline
\end{tabular}

